Nidhomul Haq: Jurnal Manajemen Pendidikan Islam

E-ISSN: 2503-1481

Terakreditasi Ristekdikti: 28/E/KPT/2019

Hal: 142-156

DOI: $10.31538 /$ ndh.v5i2.545

http://e-journal.ikhac.ac.id/index.php/nidhomulhaq

\title{
PENGARUH USIA DAN TINGKAT PENDIDIKAN TERHADAP HASIL KINERJA GURU BERDASARKAN NILAI UJIAN NASIONAL SISWA
}

\author{
Dian Purnamasari1), Robby Anzil Firdaus2), Stefy Falentino Akuba3) \\ ${ }^{1}$ Universitas Pelita Harapan \\ dian.99.p@gmail.com \\ ${ }^{2}$ Universitas Pelita Harapan \\ robby_anzil@yahoo.com \\ ${ }^{3}$ Universitas Pelita Harapan \\ stefyfalentino@gmail.com
}

\begin{abstract}
Abstrak
Salah satu indikator suksesnya sebuah sekolah adalah adanya guru-guru professional dengan latar belakang pendidikan yang baik. Guru harus sealalu meningkatkan kompetensi dirinya, salah satu caranya adalah dengan meningkatkan pendidikannya. Selain tingkat pendidikan, usia guru juga dianggap sebagai salah satu tanda profesionalisme. Tujuan dari penelitian ini adalah untuk menguji asumsi-asumsi tersebut berdasarkan hasil dari UN 2019, menggunakan data sekunder dari KEMENDIKBUD dengan menggunakan batasan bahwa definisi usia senior adalah lebih dari atau sama dengan 60 tahun. Definisi dari tingkat pendidikan tinggi adalah lebih dari sarjana (S1). Analisa menggunakan metode statistika multi regresi. Hasil yang didapat: Ada efek yang positif dari jumlah guru usia senior dan jumlah guru dengan tingkat pendidikan diatas sarjana, pada hasil nilai ujian nasional bahasa Indonesia 2019, dengan angka statistik sebesar 39\%. Semakin banyak jumlah guru usia senior, dan semakin banyak guru dengan tingkat pendidikan diatas sarja, semakin besar pula nilai hasil ujian nasional. Dengan demikian asumsi diatas terbukti.
\end{abstract}

Kata kunci: Ujian Nasional Indonesia; Kompetensi Guru; Tingkat Pendidikan; Guru Senior

\begin{abstract}
One of the indicators of successful School is that they have professional teachers with good educational background. Teachers need to always upgrading their competence, one of it is by having a higher educational degree. Other than educational degree, teacher age is also pre-assumed as sign of professionalism The purpose of this study is to do a test on those assumption to the teachers work performance based on result of UN 2019, using secondary data from KEMENDIKBUD with limitation that the definition of senior age is more or equals to 60 years old, definition of higher educational degree is higher than bachelor degree. Analyze using multi regression, statistical method. The results: There are positive effects on numbers of teachers in senior age and numbers of higher than bachelor educational degree, to Bahasa Indonesia's score 2019, with the statistical numbers of 39\% effect to the students result. The more numbers of senior teacher and the more numbers of teachers with higher level of education, then the higher the UN result. Therefore the assumption is proven.
\end{abstract}

Keywords: Indonesian Final National Exams; Teachers competence; Educational degree; Senior Teacher.

\section{PENDAHULUAN}

Dalam sistem pendidikan Indonesia, Nilai Ujian Nasional (UN) menjadi salah satu hal penting yang digunakan sebagai tolak ukur suksesnya suatu sekolah.Karena hingga saat ini ujian nasional masih digunakan sebagai tolak ukur kemajuan 
pendidikan nasional (Puspitasari \& Hasanah, 2019).

Banyak penelitian yang mencari faktorfaktor yang dapat dilakukan sekolah untuk mendapatkan nilai UN yang tinggi. Salah satu faktor yang berpengaruh pada sukses ujian nasional adalah guru. oleh karena itu biasanya guru yang disiapkan untuk kelas tingkat akhir yang akan menghadapi UN adalah guru senior dengan tingkat pendidikan yang tinggi (Ashadi \& Rice, 2016).

Dalam Undang-undang RI nomer 14 tahun 2005 tentang guru dan dosen, batas usia pensiun guru adalah 60 tahun. (Undang UndangRepublik Indonesia No 14 Tahun 2005 tentang Guru dan Dosen, 2005) Namun dalam sensus yang dilakukan oleh kemendikbud masih ada guru-guru senior yang diatas 60 tahun yang masih berkarya sebagai guru. Sehingga menarik untuk dilihat, kinerja dari guru-guru yang seharusnya sudah memasuki usia pensiun tersebut.

Indikator sekolah yang sukses salah satunya adalah memiliki guru professional dengan latar belakang pendidikan yang baik (Hakim, 2016, p. 106). Sebagai professional guru harus selalu meningkatkan kompetensi mereka, salah satu caranya dengan meningkatkan tingkat pendidikannya (Mulyasa, 2017).

Penelitian ini melihat pengaruh tingkat pendidikan guru yang lebih dari sarjana terhadap hasil pembelajaran siswa yang diwakilkan oleh nilai ujian nasional Bahasa Indonesia 2019. Untuk melihat kebenaran dari asumsi yang sudah dipaparkan di atas, dan menjadikannya sebagai faktor yang dapat meningkatkan hasil pembelajaran dari para siswa.

\section{KAJIAN LITERATUR DAN PEGEMBANGAN HIPOTESIS}

Usia pengajar sering diabaikan, karena dianggap sebagai faktor bias (Crescenzo, 2016). Dan oleh sebab itu jarang untuk dijadikan variable utama.Padahal usia pengajar, mempengaruhi persepsi siswa terhadap kehangatan dan entusiasme pengajar, yang nantinya dapat mempengaruhi keberhasilan pengajaran (Arbuckle \& Williams, 2003). Dalam penelitian ini usia pengajar (guru) dijadikan salah satu variable utama untuk dilihat pengaruhnya. Dan diharapkan nantinya dapat menjadi masukkan bagi penelitian lainnya untuk melihat usiapengajar sebagai salah satu variable penting dan bukan suatu bias yang harus dihindari.

Untuk menjelaskan variable usia guru, dilihatlah usia guru tersebut dalam sebaran generasi. Dimana setiap kelompok dalam sebaran usia, memiliki nilai pandang sendiri yang dipandang seragam dalam kelompok tersebut, terhadap kehidupan, berkaitan dengan pengalaman mereka (Dimock, 2019). 
Sebaran Generasi didefinisikan pengelompokan individu yang ideal berdasarkan tahun kelahiran. Sebaran generasi biasanya dilakukan berdasarkan samaan dalam pengalaman kerja dan pengalaman hidup, keunikan ini akan berkontribusi dalan nilai-nilai yang dianut dan terjadi pada generasi-generasi tersebut (Jiří, 2016).

Sebaran generasi berdasarkan tahun kelahiran dikelompokkan menjadi, Silent yaitu orang orang yang terlahir pada range tahun 1928-1945, sehingga saat ini mereka berusia $>74$ tahun. Baby boomer : mereka yang terlahir pada range tahun 1946-1964, sehingga saat ini range usia mereka adalah 55 - 73 tahun. Generasi X : mereka yang terlahir pada range tahun kelahiran 1965 - 1980, sehingga saat ini range usia mereka adalah 39 - 54 tahun. Millennials (Generasi Y) : mereka yang terlahir pada tahun kelahiran 1981-1996, sehingga range usia mereka saat ini 23-38 tahun. Generasi Z : mereka yang terlahir pada range tahun kelahiran 1997-2012, sehingga saat ini usia mereka adalah $22-7$ tahun (Dimock, 2019).

Generasi senior yaitu generasi baby boomer dengan range tahun kelahiran 1946 sampai 1960. Memiliki karakter setia berdedikasi tinggi, suka bekerja keras dan menerima arahan dengan baik. Karakter negatif yang ada pada generasi baby boomer adalah individualis, sinis dan egoistic. Baby boomer dianggap generasi yang memiliki sosial tinggi (Starks, 2013).

Di tahun 2019 ini mayoritas orang tua Siswa SMA merupakan generasi baby boomer ataupun anak dari orang tua yang berasal dari generasi baby boomer. Itu sebabnya mayoritas orang tua tersebut lebih mempercayakan pendidikan putraputri mereka pada guru yang berasal dari generasi baby boomer (guru senior).

Apalagi dengan karakteristik dari generasi baby boomer yang mendekati kategori guru yang baik yang dideskripsikan oleh Çelikten dan Can pada 2003, dalam artikel yang dituliskan olah King pada tahun 2019. Generasi Baby boomer memiliki sebagian besar karakteristik guru yang baik yaitu dapat dipercaya, toleransi tinggi dan objektif. Menjadikan kepercayaan pada guru senior dari generasi baby boomer ini cukup tinggi (McInerney, Ganotice, King, Marsh, \& Morin, 2015).

Generasi baby boomer sebenarnya sudah berkurang jumlah dalam dunia kerja.Generasi millennial muncul sebagai pengganti baby boomer. Namun asumsi yang melekat pada generasi millennials yaitu tidak loyal dan terlalu santai serta komitmennya rendah(Thompson \& Gregory, 2012), menyebabkan guru dengan usia yang lebih senior yang lebih disukai oleh para orang tua dari siswa-siswa SMA tesebut. 
Di Indonesia mayoritas bidang pekerjaan termasuk di dalamnya untuk bidang pendidikan, batas usia untuk mendaftar adalah 35 tahun, bila lebih dari 35 tahun dianggap sudah tidak bisa diubah dan tidak terlalu membawa dampak baik. Dan usia pensiun guru pun dibatasi di usia 60 tahun, sehingga perlu dilihat apakah pengaruh dari guru yang berusia senior di usia sama dengan atau lebih dari 60 tahun dan masih aktif terhadap hasil pembelajaran dari para siswa.

Dinyatakan Tilaar dalam bukunya kaleidoskop pendidikan Indonesia "Guru mempunyai kewajiban dan tanggung jawab moral untuk mengembangkan dan mempertahankan mutu serta meningkatkan mutu profesi, pembinaan dan peningkatan akademis profesi guru merupakan kewajiban moral dari guru itu sendiri. Untuk menghasilkan masyarakat berdasarkan ilmu pengetahuan", hal ini termasuk didalamnya meningkatkan keberhasilan siswa (Prof. Dr. H.A.R Tilaar \& Tilaar, 2012).

Beberapa penelitian setuju bahwa guru dengan tingkat kualitas yang tinggi (termasuk dalam tingkat pendidikannya) akan menghasilkan siswa dengan tingkat keberhasilan yang tinggi pula. Kebutuhan akan guru dan tenaga kependidikan yang terlatih dan selalu up to dates diketahui sebagai hal yang esensial bagi dunia pendidikan (Meroni, Vera-Toscano, \& Costa, 2015).

Keberhasilan siswa dan ketertarikan siswa pada pendidikan adalah hal yang sangat diinginkan dalam suatu sekolah (Mujiono, 2016). Kemampuan pedagogik guru serta pengetahuannya yang luas sudah teridentifikasi sebagai faktor utama dalam memprediksi keberhasilan siswa (Keller, Neumann, \& Fischer, 2017).

Sumber Daya Manusia (SDM) berkualitas hanya dapat direkayasa melalui pendidikan yang dirancang oleh guru profesional dan bermutu.Siswa-siswa yang berkualitas didapatkan dari guru professional dan bermutu (Mulyasa, 2017).

Sebenarnya dalam kriteria profesionalisme dalam pekerjaan berdasarkan C.O. Houle, baik senioritas usia maupun tingkat pendidikan tidak termasuk di dalamnya, namun salah satu unsur di dalamnya adalah memiliki landasan pengetahuan yang kuat. Guru yang senior secara usia dan atau memiliki tingkat pendidikan tinggi seharusnya sudah memiliki landasan pengalaman dan pengetahuan yang kuat, berarti guru dengan kedua kriteria tersebut seharusnya memiliki tingkat profesionalisme tinggi yang pada akhirnya dapat membantu keberhasilan siswa dalam pembelajarannya yang dibuktikan dengan tingginya hasil ujiannya (Suyanto \& Djihad, 2013). 
Berdasarkan beberapa pernyataan diatas dibuatlah hipotesa yang dijadikan dasar dalam penelitian ini, yaitu :

Hipotesis 1 : Guru berusia senior yang lebih dari usia 60 tahun, kinerjanya mempengaruhi hasil pembelajaran siswa.

Hipotesis 2 : Guru dengan tingkat pendidikan lebih dari sarjana, kinerjanya memberikan pengaruh kepada hasil pembelajaran siswa.

\section{METODE PENELITIAN}

Metode penelitian yang digunakan adalah metode kuantitatif deskriptif, dikarenakan data berupa numerik yang kemudian dijelaskan secara deskriptif (Prabhat \& Pandey, 2016). Statistik deskriptif menyusun data dan menyajikan data dalam bentuk table frekuensi atau grafik dan selanjutnya diukur nilai-nilai statistiknya (Suliyanto, 2018)

Uji statistik menggunakan uji multi regresi karena memiliki lebih dari satu variable bebas. Dengan menguji pula asumsi klasik untuk validitas dan signifikansi data, berupa : uji estimasi equasi, uji linearity in parameter, uji korelasi, uji mutikolinieritas, uji heteroskedasitas, uji normalitas dan uji autocorrelation (Ghozali, 2011). Alat uji berupa aplikasi eviews 10 .

Menggunakan data
KEMENDIKBUD untuk
persentase
jumlah guru senior dan persentase jumlah

guru dengan tingkat pendidikan diatas Sarjana (S1) di seluruh 34 propinsi Indonesia, sebagai variable independen. Guru senior disini adalah guru dengan usia sama dengan atau lebih dari 60 tahun, generasi baby boomer. Variable dependen menggunakan data nilai ujian nasional 2019 mata pelajaran Bahasa Indonesia. Mata pelajaran Bahasa Indonesia diambil karena mata pelajaran tersebut diujikan pada seluruh Siswa baik dari kelas penjurusan IPA maupun IPS, dan karena Bahasa Indonesia adalah bahasa nasional kita, diharapkan mata pelajaran ini dikuasai dengan baik secara merata oleh seluruh siswa di ke 34 propinsi di Indonesia.

Seluruh data berasal dari Puspendik Kemendikbud sampling dilakukan oleh pihak Kemendikbud. Metode sampling survey, penentuan sampel menggunakan multi stages probability sampling. Tahap pertama memilih kabupaten/kota sampel, tahap kedua memilih sekolah sampel, dan tahap ketiga memilih siswa sampel.Jumlah sample 2000 siswa dari 250 sekolah yang tersebar di seluruh Indonesia.Dalam program Assesment Kompetensi Siswa Indonesia (AKSI) untuk pemetaan capaian pendidikan, bertujuan memantau mutu pendidikan nasional. 


\section{HASIL DAN PEMBAHASAN}

Total Data Penelitian, dapat dilihat dalam 3 tabel di bawah ini.

Diagram 1. Nilai UN Bahasa 2019

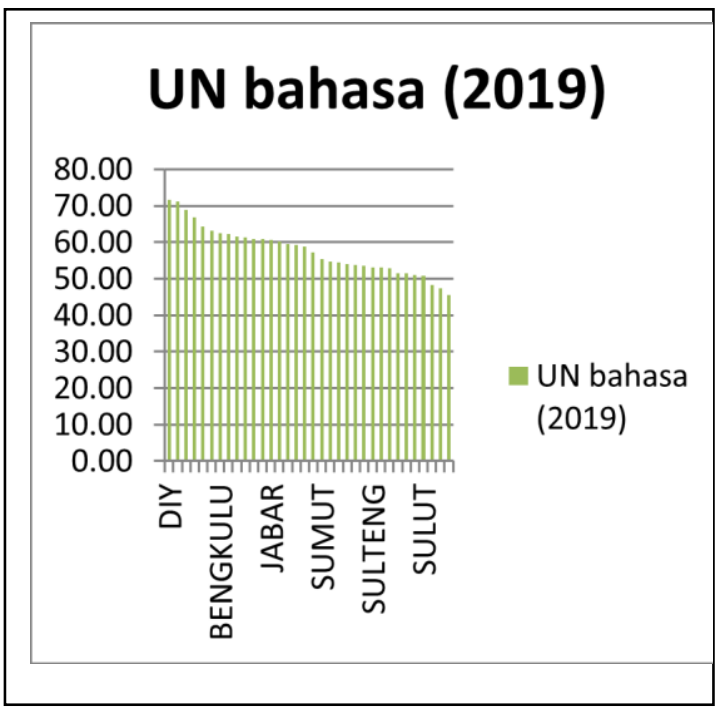

Diagram 2. Persentase Jumlah Guru Berusia Senior.

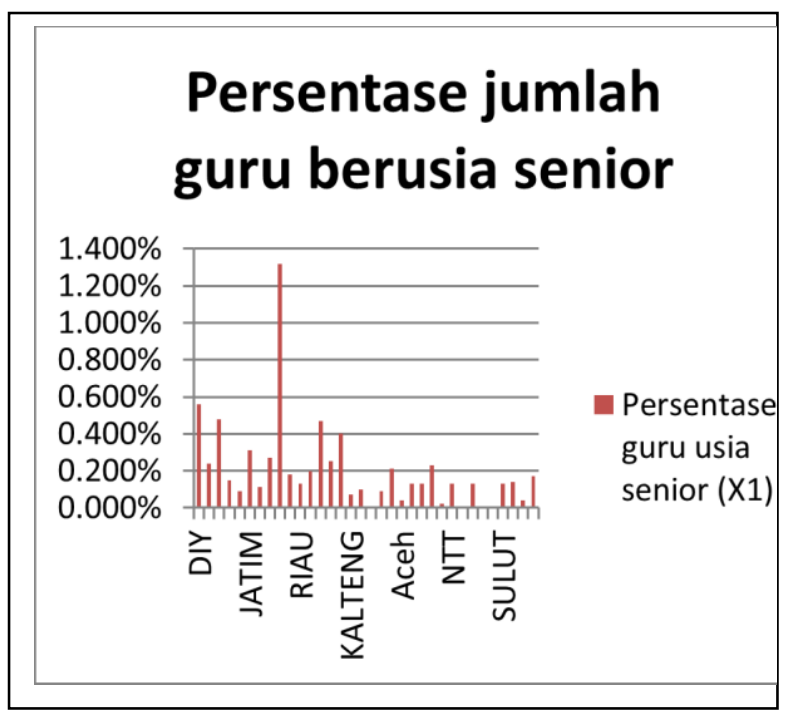

Diagram

3. Persentase

Guru

Berpendidikan Lebih dari S1

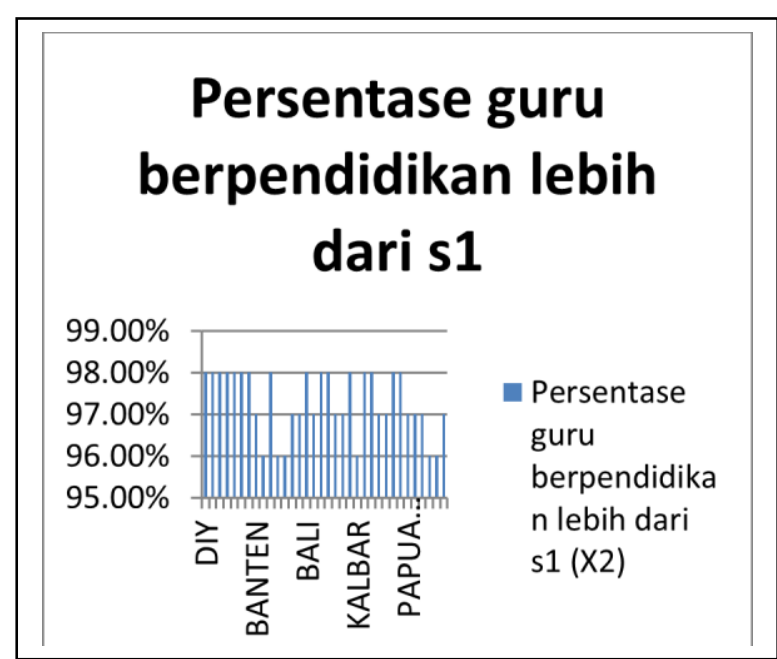

Jumlah guru berusia senior dan jumlah guru yang berpendidikan lebih dari s1 dijadikan dalam bentuk persentase dengan pembanding jumlah total guru pada propinsi tersebut. Guru berusia senior pada data ini adalah guru dengan usia lebih dari atau sama dengan 60 tahun (Baby boomer).

Hasil Uji Statistik.

Pengujian Uji estimasi equasi

Equasi uji :

$\mathrm{Y}=\mathrm{C} \mathrm{X} 1 \mathrm{X} 2$

Dimana :

$$
\begin{aligned}
\mathrm{Y}= & \text { Nilai UN SMA Bahasa } \\
\mathrm{C}= & \text { Constanta } \\
\mathrm{X} 1= & \text { Guru SMA berusia senior } \\
& (>60 \text { tahun }) \\
\mathrm{X} 2= & \text { Guru SMA yang berpendidikan } \\
& \text { lebih dari S1. }
\end{aligned}
$$


Tabel 1. Hasil uji estimasi equasi

\begin{tabular}{|c|c|c|c|c|}
\hline \multicolumn{5}{|c|}{$\begin{array}{l}\text { Dependent Variable: UN } \\
\text { Method: Least Squares } \\
\text { Date: } 10 / 27 / 19 \text { Time: } 07: 00 \\
\text { Sample: } 134 \\
\text { Included observations: } 34\end{array}$} \\
\hline Variable & Coefficient & Std. Error & t-Statistic & Prob. \\
\hline & -309.8461 & 118.9465 & -2.604919 & 0.0140 \\
\hline GURUUSIASENIOR & 1331.601 & 374.3191 & 3.557396 & 0.0012 \\
\hline S2 & 375.0647 & 122.1548 & 3.070405 & 0.0044 \\
\hline R-squared & 0.388294 & \multicolumn{2}{|c|}{ Mean dependent var } & 57.69382 \\
\hline Adjusted R-squared & 0.348829 & \multicolumn{2}{|c|}{ S.D. dependent var } & 6.557708 \\
\hline S.E. of regression & 5.291752 & \multicolumn{2}{|c|}{ Akaike info criterion } & 6.254273 \\
\hline Sum squared resid & 868.0817 & \multicolumn{2}{|c|}{ Schwarz criterion } & 6.388952 \\
\hline Log likelihood & -103.3226 & \multirow{2}{*}{\multicolumn{2}{|c|}{$\begin{array}{l}\text { Hannan-Quinn criter. } \\
\text { Durbin-Watson stat }\end{array}$}} & 6.300202 \\
\hline F-statistic & 9.838983 & & & 1.618398 \\
\hline Prob(F-statistic) & 0.000491 & & & \\
\hline
\end{tabular}

\section{Indikator :}

1. R-square (R2) : menjelaskan hubungan variable independent dengan dependent, seberapa besar independent menjelaskan mengenai dependent. Semakin besar R2 semakin baik.

2. Probability F statistic : menjelaskan signifikansi data. Dengan syarat penerimaan $0.00<x<0.05$.

3. T parameter probability, menjelaskan kevalid-an data per parameter. Dengan syarat penerimaaan $0.00<$ prob $<0.05$

Hasil dan pembahasan :

1. $\mathrm{R} 2=0.39$ menjelaskan persentase jumlah guru SMA berusia senior dan guru SMA yang berpendidikan lebih dari S1 dan, menjelaskan hasil nilai Ujian Nasional bahasa per propinsi sebesar 39\%.

2. Probabilitas F statistic 0.0005 , dibawah 0.05 artinya data signifikan / bernas.

3. Probabilitas setiap parameter dibawah 0.05 artinya data valid. Hipotesis diterima.

\section{Uji linearity in parameter}

Tabel 2. Hasil uji linieritas

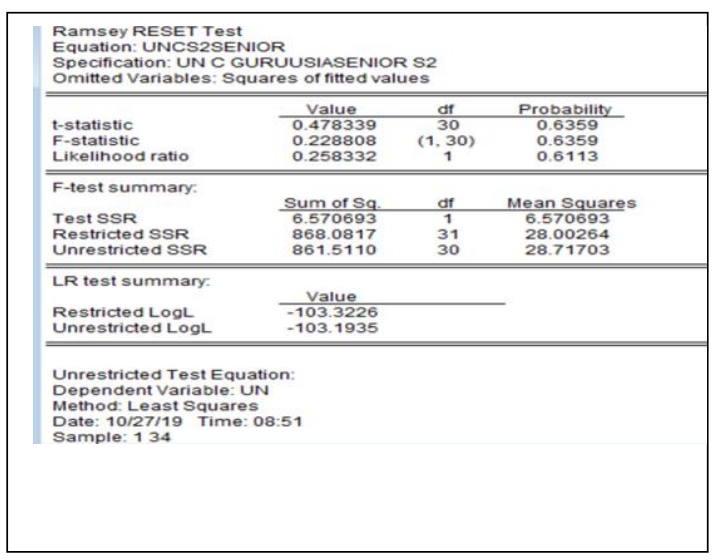

Menggunakan stability diagnostic : Ramsey

Reset Test.

Indikator :

Probability F statistic : menjelaskan linieritas variable dalam parameter. Dengan syarat penerimaan $\mathrm{F}$ statistic $>0.05$

Hasil :

F statistical probability diatas 0.05 artinya data linier dalam parameter

\section{Uji Korelasi.}

Tabel 3. Hasil uji korelasi.

\begin{tabular}{|c|c|c|c|c|}
\hline \multicolumn{4}{|c|}{ Correation } \\
\hline & S2 & GURUUSA . & & \\
\hline S2 & 1.00000 & 0.123896 & & \\
\hline GURUSSA. & 0.123896 & 1.00000 & & \\
\hline & & & & \\
\hline & & & & \\
\hline
\end{tabular}

Indikator :

Angka korelasi antar variable harus dibawah 0.8 agar variable ada pembeda dan tidak terlalu mirip satu sama lainnya.

Hasil : 
Angka korelasi variable tingkat pendidikan guru lebih dari S1 (ditunjukkan dengan nama variable S2) mempunyai nilai hubungan dengan variable guru usia senior (ditunjukkan dengan nama variable guru usia) sebesar -0.124. Angka tersebut berada di bawah 0.8 menunjukkan bahwa kedua variable tersebut berbeda satu sama lainnya, dengan hubungan korelasi bersifat negatif (berkebalikan)

\section{Uji Multi Kolenieritas.}

Tabel 4. Hasil uji multi kolenieritas.

\begin{tabular}{|c|c|c|c|}
\hline \multicolumn{4}{|c|}{$\begin{array}{l}\text { Variance Inflation Factors } \\
\text { Date: } 10 / 27 / 19 \text { Time: } 09: 30 \\
\text { Sample: } 134 \\
\text { Included observations: } 34\end{array}$} \\
\hline Variable & $\begin{array}{l}\text { Coefficient } \\
\text { Variance }\end{array}$ & $\begin{array}{l}\text { Uncentered } \\
\text { VIF }\end{array}$ & $\begin{array}{c}\text { Centered } \\
\text { VIF }\end{array}$ \\
\hline C & 14148.28 & 17178.44 & NA \\
\hline GURUUSIASENIOR & 140114.8 & 1.676216 & 1.015590 \\
\hline S2 & 14921.79 & 17151.41 & 1.015590 \\
\hline
\end{tabular}

Menggunakan coefisien diagnostic, variance inflation factors test.

Indikator :

Angka centered VIF tidak boleh lebih besar dari pada 5

Hasil :

Dengan lambang variable Guru usia senior untuk variable persentase jumlah guru berusia senior, dan lambang variable S2 untuk variable persentase jumlah guru yang memiliki tingkat pendidikan diatas sarjana (S1), didapatkan hasil angka centered VIF tiap variable 1.0. angka ini dibawah batas 5, maka tidak ada masalah multi kolenieritas antara variable yang digunakan dalam pengujian.

\section{Uji normalitas}

Diagram 4. Hasil uji normalitas.

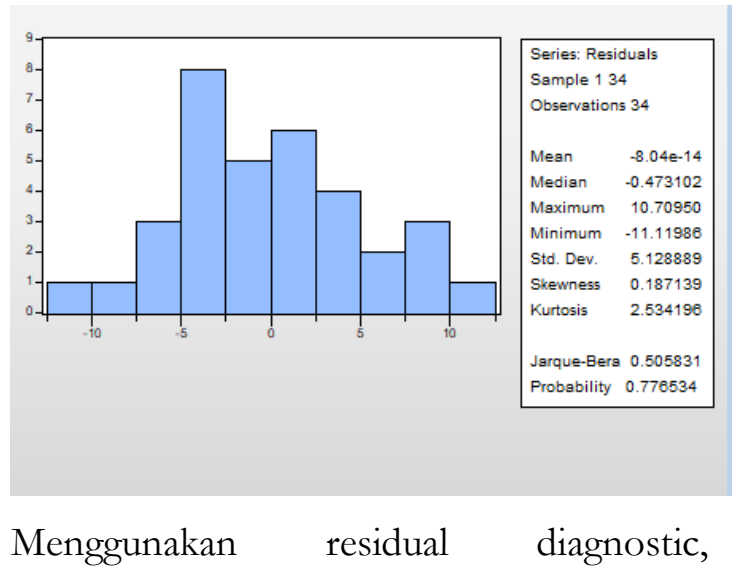

histogram normality test.

Indikator :

Jarque Bera : menyatakan normalitas data. Dengan syarat penerimaan Jarque Bera > 0.05

Hasil :

Jarque Bera hasil pengujian menunjukkan angka 0.506, angka tersebut sudah diatas 0.05 , yang berarti distribusi data normal.

\section{Uji heteroskedasitas.}

Tabel 5. Hasil uji heteroskedasitas.

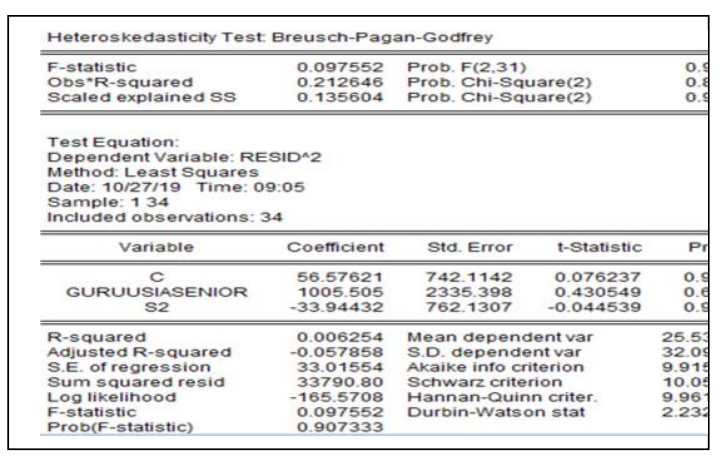


Menggunakan residual diagnostic,

Heteroskedasticity test : Breusch-Pagan-

Godfrey.

Indikator :

Probability F statistic : menyatakan error dalam variabel tersebut stabil atau tidak berubah ubah. Dengan syarat penerimaan F statistic $>0.05$

Hasil :

Prob uji $f(2,31)$ menunjukkan nilai 0.9073, nilai tersebut sudah diatas batas 0.05 yang berarti hasil uji stabil, tidak bias.

\section{Uji auto correlation.}

\begin{tabular}{|l|r|}
\hline $\begin{array}{l}\text { t-beta Jumlah } \\
\text { guru senior }\end{array}$ & 2.717 \\
\hline $\begin{array}{l}\text { t-beta Jumlah } \\
\text { guru lebih dari S1 }\end{array}$ & 2.350 \\
\hline
\end{tabular}

Tabel 6. Hasil uji auto korelasi.

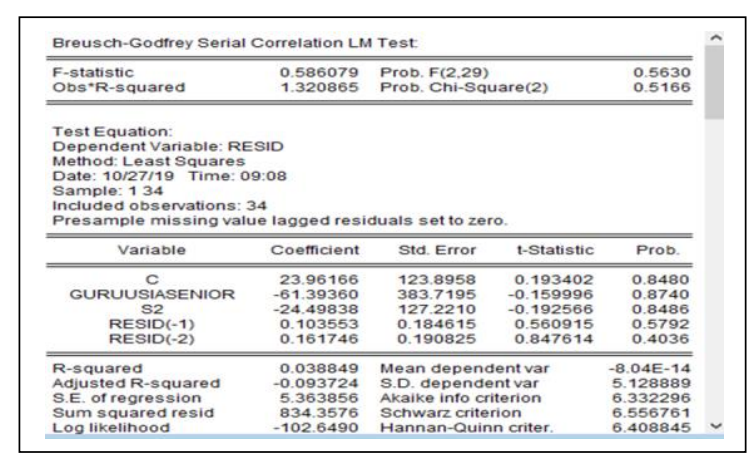

Menggunakan residual diagnostic, Breusch-

Godfrey serial correlation LM test.

Indikator :

1. Prob F: menyatakan korelasi variable data dengan error. Dengan syarat penerimaan prob $\mathrm{F}>0.05$
2. Prob Chi Square : menyatakan korelasi variable data dengan error. Dengan syarat penerimaan prob Chi Square $>0.05$

Hasil :

1. Probabilitas uji F(2.29) menunjukkan angka 0.5630, angka tersebut sudah diatas 0.05. Hal ini menunjukan data terbebas dari korelasi dengan error.

2. Probabilitas uji chi-square(2) menunjukkan angka 0.5166, angka tesebut juga sudah diatas 0.05. Hal ini menunjukan data terbebas dari korelasi dengan error.

\section{Uji Kekuatan Pengaruh}

Tabel 7. Hasi uji T

\begin{tabular}{|l|l|}
\hline t-beta Jumlah guru senior & 2.717 \\
\hline $\begin{array}{l}\text { t-beta Jumlah guru lebih } \\
\text { dari S1 }\end{array}$ & 2.350 \\
\hline
\end{tabular}

t-beta Jumlah guru senior 2.717

t-beta Jumlah guru lebih dari S1 2.350

Pengujian : menggunakan uji T korelasi.

Indikator :

Angka $T$ beta menunjukkan kekuatan pengaruh variable.

Hasil :

Angka $\mathrm{T}$ beta pada kedua variable yaitu variable jumlah guru senior dan jumlah guru dengan tingkat pendidikan lebih dari S1 menunjukkan angka yang positif, yang diartikan bahwa keduanya memiliki hubungan yang positif terhadap variable nilai ujian nasional Bahasa Indonesia. Jika jumlah guru senior dan jumlah guru 
dengan tingkat pendidikan lebih dari S1 meningkat maka nilai ujian nasional Bahasa Indonesia akan meningkat pula.

Pembahasan hasil penelitian ini adalah. Berdasarkan hasil pengujian asumsi, maka dapat ditarik kesimpulan bahwa hipotesis yang diajukan diterima.

Untuk lebih membuktikan hasil uji $\mathrm{T}$, hipotesis 1 dibuatlah diagram.4.

Diagram 5. Penyatuan Jumlah guru senior dengan nilai UN Bahasa.

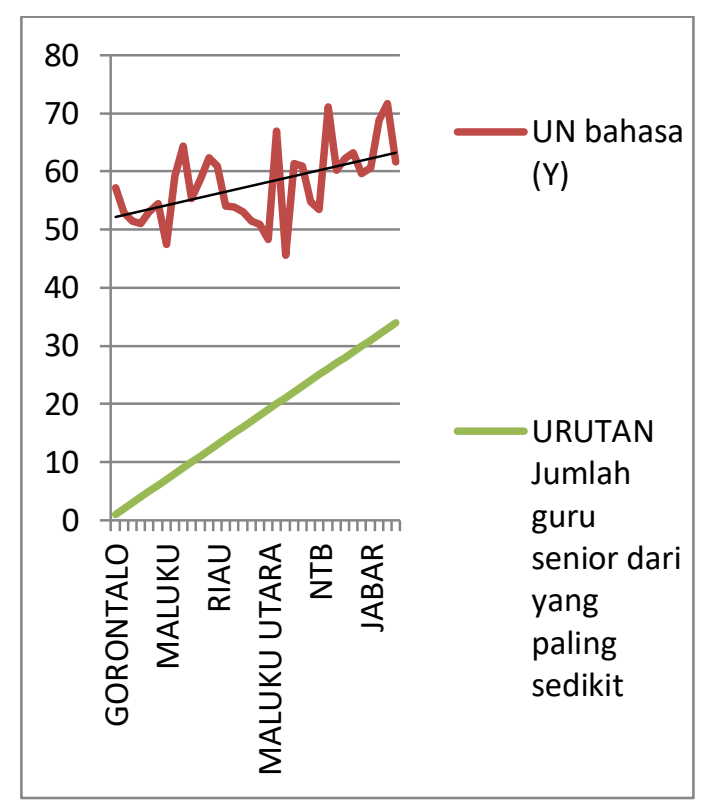

Berdasarkan data yang ada, dibuatlah grafik urutan jumlah guru senior dari propinsi yang paling sedikit jumlah guru seniornya ke yang paling banyak, kemudian disatukan dengan grafik nilai ujian nasional Bahasa Indonesia 2019. Dibuatlah trend line linier pada nilai ujian nasional, dari grafik dapat terlihat bahwa ada pengaruh positif dari jumlah guru senior ke hasil nilai ujian nasional, seperti yang dinyatakan dalam hipotesis 1 .Semakin banyak jumlah guru senior pada suatu propinsi, nilai ujian nasional Bahasa Indonesianya semakin tinggi.

Untuk lebih membuktikan hasil uji $\mathrm{T}$, hipotesis 2 dibuatlah diagram. 6 .

Diagram 6. Penyatuan Jumlah guru berpendidikan lebih dari S1 dengan nilai UN Bahasa.

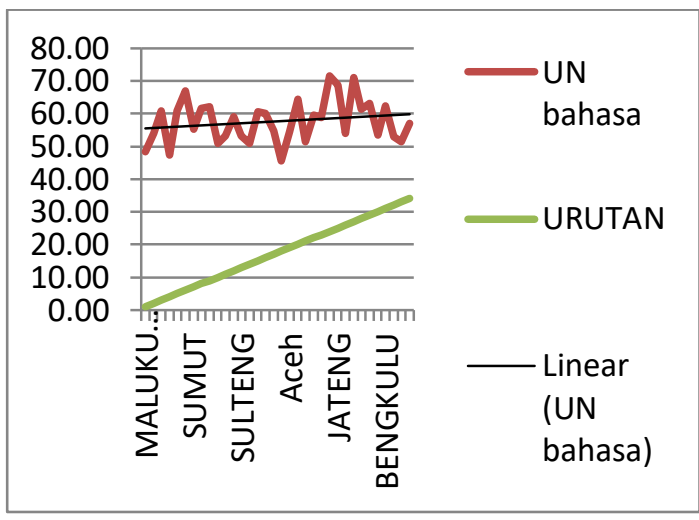

Berdasarkan data yang ada, dibuatlah grafik urutan jumlah guru berpendidikan lebih dari S1, dari propinsi yang paling sedikit jumlah guru dengan klasifikasi tersebut, ke yang paling banyak, kemudian disatukan dengan grafik nilai ujian nasional Bahasa Indonesia 2019. Dibuatlah trend line linier pada nilai ujian nasional, dari grafik dapat terlihat bahwa ada pengaruh positif dari jumlah guru berpendidikan lebih dari S1 ke hasil nilai ujian nasional, seperti yang dinyatakan dalam hipotesis 2.Semakin banyak jumlah guru yang berpendidikan lebih dari S1 pada suatu propinsi, nilai ujian nasional Bahasa Indonesianya semakin tinggi.Walaupun pengaruh ini tidak lebih kuat daripada pengaruh dari jumlah guru senior. 
Hasil uji sejalan dengan penelitian pengaruh guru pada keberhasilan siswanya bisa dijelaskan dengan tiga kelas variable secara umum, yaitu kemampuan guru, motivasi dan situasi kerjanya.Semakin tinggi ketiga variable tersebut, semakin baiklah keberhasilan siswa yang dapat dicapai. (Rowan, Chiang, \& Miller, 1997)

Hasil juga sesuai penelitian lain yang menyebutkan bahwa guru senior mempunyai motivasi yang tinggi yang dapat mengakibatkan tingkat keberhasilan siswanya pun akan tinggi (Mertler, 2016).

Penelitian dari Alufohai dan Ibhafidon pada 2015 juga menyatakan bahwa usia guru berpengaruh pada tingkat keberhasilan siswa (Alufohai \& E, 2015). Namun berkebalikan dengan hasil yang didapatkan oleh Delhanty di tahun 1977 yang tercantum dalam artikel yang sama(Alufohai \& E, 2015), dimana temuan Delhanty tersebut menyatakan tidak ada perbedaan pada guru senior maupun guru muda.

Pada variable jumlah guru dengan tingkat pendidikan yang melebih S1, hasil didapatkan sejalan penelitian Honicke dan Broadbent, 2016, bahwa tingkat pengetahuan guru (dihubungkan dengan tingkat pendidikan) secara positif memprediksi hasil yang didapatkan siswanya. Hasil juga sejalan penelitian Goldhaber dan Brewer, tahun 1996. Yang menyatakan bahwa tingkat pendidikan guru mempengaruhi hasil yang didapatkan oleh siswa, selama pendidikan guru tersebut sesuai dengan mata pelajaran yang diajarkan pada siswanya (Honicke \& Broadbent, 2016).

Persamaan dan perbedaan yang didapatkan dari hasil pengujian ini dengan penelitian-penelitian yang lain sangat mungkin terjadi, hal ini karena, Tahun penelitian berbeda yang dapat mengakibatkan pola pemikiran masyarakatnya pun berbeda sesuai masanya. Tempat penelitian berada pada negara yang berbeda juga dapat mengakibatkan bedanya pandangan dan pola pikir masyarakat dalam negara tersebut, terhadap senioritas dan tingkat pendidikan sesorang. Variable yang diambil sama, sehingga sangat memungkinkan hasil yang didapat pun mendekati.

Berdasarkan hasil pengujian data, asumsi yang selama ini beredar di masyarakat bahwa, jumlah guru berusia senior (generasi baby boomer) dan jumlah guru dengan pendidikan yang lebih tinggi, adalah benar mempengaruhi, dapat meningkatkan prestasi belajar siswa, dilihat dari hasi UN Bahasa Indonesia 2019, pada ke-34 propinsi di Indonesia. Asumsi terbukti.

Pengujian ini juga membuktikan bahwa variable usia dapat digunakan sebagai salah satu variable utama dalam penelitian 
pendidikan, melalui penggolongan sebaran generasi, mengurangi bias.

Secara aplikatif pengujian ini membuktikan bahwa guru di usia senior (generasi baby boomer) masih dapat berkarya dengan baik bahkan dapat meningkatkan hasil pembelajaran siswa. Walaupun nantinya akan ada faktor-faktor pendukung lain yang perlu diuji. Pengujian juga membuktikan bahwa guru harus terus meningkatkan kompetensi dirinya termasuk dalam peningkatan jenjang pendidikan dirinya, karena guru dengan pendidikan yang lebih tinggi menghasilkan hasil pembelajaran yang lebih baik pula.

Hasil ini mendukung usulan dari Mendikbud Muhadjir Effendy pada Agustus 2019, bahwa usia pensiun guru adalah 60 tahun namun masih tetap dapat mengabdi di dunia pendidikan. Usulan ini untuk guru usia senior yang masih beredia mengabdi dan sanggup (Masyarakat \& Kebudayaa, 2019).

\section{KESIMPULAN}

Berdasarkan pengujian yang dilakukan Didapatkan kesimpulan bahwa hasil pengujian, pengaruh jumlah guru usia senior (generasi baby boomer) dan jumlah guru yang berpendidikan lebih dari s1, berpengaruh positif terhadap hasil pembelajaran siswa yang diwakili oleh nilai UN Bahasa Indonesia 2019.
Berdasarkan pengujian ini, guru berusia senior diatas 60 tahun masih dapat memberikan kinerja baiknya dalam pembelajaran yang didasarkan pada hasil nilai ujian nasional siswa. Begitu pula jumlah guru yang berpendidikan lebih dari Sarjana (S1) juga memberikan pengaruh yang positif terhadap hasil ujian nasional siswa, walaupun hasilnya tidak sesignifikan pengaruh jumlah guru yang berusia senior.

Hasil dari pengujian diharapkan dapat meningkatkan motivasi para guru untuk terus mencari ilmu, meningkatkan kompetensi dan pengalaman dalam dunia pendidikan, serta tidak takut untuk berkomitmen dalam berkarier sebagai guru, agar dapat memberikan pembelajaran yang terbaik untuk para siswa.

Bagi guru berusia senior (generasi baby boomer), pengujian ini dapat memotivasi untuk terus memberi yang terbaik bagi siswanya, karena sesuai hasil pengujian, mereka memberikan pengaruh positif terhadap hasil nilai ujian bagi siswanya.

Penelitian ini juga dapat dijadikan dasar pengubahan kriteria pencarian tenaga kerja guru yang mayoritas membatasi usia di 35 tahun, karena bahkan di usia senior pun guru dapat memberikan yang terbaik bagi siswanya. 


\section{REFERENSI}

Alufohai, P. J., \& E, I. H. (2015). Influence of teachers' age, marital status and gender on students' accademic achievement. Asian Journal of Educational Research, 3(4), 60-66. Retrieved from www.multidisciplinaryjournals.com $\%$ $0 \mathrm{~A} 60$

Arbuckle, J., \& Williams, B. D. (2003). Students' Perceptions of Expressiveness: Age and Gender Effects on Teacher Evaluations. Sex Roles, 49(9-10), 507-516. https://doi.org/10.1023/A:10258327 07002

Ashadi, A., \& Rice, S. (2016). High stakes testing and teacher access to professional opportunities: lessons from Indonesia. Journal of Education Policy, $\quad 31(6), \quad$ 727-741. https://doi.org/10.1080/02680939.2 016.1193901

Crescenzo, P. (2016). Journal of health and social sciences. Journal of Health and Social Sciences, 1(3), 287-292. Retrieved from

https://doaj.org/article/0aae2513ab6 44fc881987bdcb0fec196

Dimock, M. (2019). Where Millennials end and Generation $\mathrm{Z}$ begins | Pew Research Center. Pew Research Center, 1-8. Retrieved from http://www.pewresearch.org/facttank/2019/01/17/where-millennialsend-and-generation-z-begins/

Ghozali, I. (2011). Aplikasi Analisis Multivariate dengan Program SPSS. Semarang: Universitas Diponogoro.

Goldhaber, D. D., \& Brewer, D. J. (1996). Evaluating the effect of teacher degree level on performance. Academic Achievement, (21).

Hakim, M. N. (2016). Implementasi Manajemen Berbasis Sekolah Dalam Mewujudkan Sekolah Islam Unggulan. Nidhomul Haq: Jurnal Manajemen Pendidikan Islam, 1(2), 104 114.

https://doi.org/10.31538/NDH.V1I 2.7

Honicke, T., \& Broadbent, J. (2016). The influence of academic self-efficacy on academic performance: A systematic review. Educational Research Review, 17, 63-84. https://doi.org/10.1016/j.edurev.201 5.11 .002

Jiř́, B. (2016). The Current Generations: The Baby Boomers, $\mathrm{X}, \mathrm{Y}$ and $\mathrm{Z}$ in the Context of Human Capital Management of the 21st Century in Selected Corporations in the Czech Republic. Littera Scripta, (2), 25-45.

Keller, M. M., Neumann, K., \& Fischer, H. 
E. (2017). The impact of physics teachers' pedagogical content knowledge and motivation on students' achievement and interest. Journal of Research in Science Teaching, 54(5), 586-614. https://doi.org/10.1002/tea.21378

Masyarakat, B. K. dan L., \& Kebudayaa, K. P. dan. (2019). Usia Pensiun Guru PNS Tetap 60 Tahun. Retrieved February 1, 2020, from Siaran Pers BKLM, Nomor: 254/Sipres/A5.3/VIII/2019 website: https://www.kemdikbud.go.id/main /blog/2019/08/usia-pensiun-gurupns-tetap-60-tahun

McInerney, D. M., Ganotice, F. A., King, R. B., Marsh, H. W., \& Morin, A. J. S. (2015). Exploring commitment and turnover intentions among teachers: What we can learn from Hong Kong teachers. Teaching and Teacher Education, 52, 11-23. https://doi.org/10.1016/j.tate.2015.0 8.004

Meroni, E. C., Vera-Toscano, E., \& Costa, P. (2015). Can low skill teachers make good students? Empirical evidence from PIAAC and PISA. Journal of Policy Modeling, 37(2), 308-323. https://doi.org/10.1016/j.jpolmod.2 015.02 .006

Mertler, C. A. (2016). Should I Stay or
Should I Go? Understanding Teacher Motivation, Job Satisfaction, and Perceptions of Retention among Arizona Teachers. International Research in Higher Education, 1(2), 34-45. https://doi.org/10.5430/irhe.v1n2p3 4

Mujiono. (2016). Penerapan Model Pembelajaran Think-Pair-Share dengan Peta Konsep untuk Meningkatkan Hasil Belajar. Jurnal Manajemen Pendidikan Islam (Nidhomul Haq), 17 (1), https://doi.org/10.17509/jpm.v1i1.3 349

Mulyasa, H. E. (2017). Uji Kompetensi dan Penilaian Kinerja Guru (3rd ed.; N. N. Muliawati, Ed.). Bandung: PT Remaja Rosdakarya.

Prabhat, P., \& Pandey, M. M. (2016). Research Methodology: Tools and Techniques (Vol. 0). Buzau: BRIDGE CENTER.

Prof. Dr. H.A.R Tilaar, M. S. E., \& Tilaar, H. A. . (2012). Kaleidoskop Pendidikan Nasional (T. Brahim, Ed.). Jakarta: Kompas.

Puspitasari, Y., \& Hasanah, N. (2019). NASIONAL TERHADAP HASIL BELAJAR MATEMATIKA SISWA KELAS X MANURUL FATA TAHUN PELAJARAN 2017 / 2018. 6(1), 34-43. 
Rowan, B., Chiang, F. S., \& Miller, R. J. (1997). Using research on employees' performance to study the effects of teachers on students' achievement. Sociology of Education, 70(4), 256-284. https://doi.org/10.2307/2673267

Starks, A. (2013). The Forthcoming Generational Workforce Transition and Rethinking Organizational Knowledge Transfer. Journal of Intergenerational Relationships, 11(3), 223-237.

https://doi.org/10.1080/15350770.2 013.810494

Suliyanto. (2018). Metode Penelitian Bisnis (A. Cristian, Ed.). Yogyakarta: Andi Offset.

Suyanto, S., \& Djihad, A. (2013). Bagaimana Menjadi Calon Guru dan Guru Profesional (2nd ed.; S. La Ode, Ed.). Yogyakarta: MULTI PRESSINDO.

Thompson, C., \& Gregory, J. B. (2012). Managing Millennials: A Framework for Improving Attraction, Motivation, and Retention. Psychologist-Manager Journal, 15(4), 237-246. https://doi.org/10.1080/10887156.2 012.730444

Undang UndangRepublik Indonesia No 14 Tahun 2005 tentang Guru dan Dosen. (2005). Undang-Undang Republik Indonesia, Tentang Guru dan Dosen. Pemerintah Indonesia.
Retrieved from http://sumberdaya.ristekdikti.go.id/ wp-content/uploads/2016/02/uunomor-14-tahun-2005-ttg-guru-dandosen.pdf 